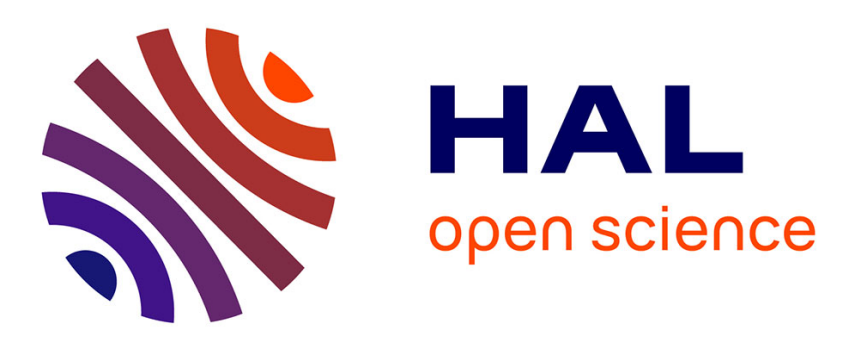

\title{
Improvement of the shape memory effect of a Fe-Mn-Cr-Si-Ni by original thermomechanical treatments
}

L. Federzoni, G. Guénin, M. Mantel

\section{- To cite this version:}

L. Federzoni, G. Guénin, M. Mantel. Improvement of the shape memory effect of a Fe-Mn-Cr-SiNi by original thermomechanical treatments. Journal de Physique IV Proceedings, 1993, 03 (C7), pp.C7-557-C7-560. 10.1051/jp4:1993792 . jpa-00252212

\section{HAL Id: jpa-00252212 https://hal.science/jpa-00252212}

Submitted on 1 Jan 1993

HAL is a multi-disciplinary open access archive for the deposit and dissemination of scientific research documents, whether they are published or not. The documents may come from teaching and research institutions in France or abroad, or from public or private research centers.
L'archive ouverte pluridisciplinaire HAL, est destinée au dépôt et à la diffusion de documents scientifiques de niveau recherche, publiés ou non, émanant des établissements d'enseignement et de recherche français ou étrangers, des laboratoires publics ou privés. 


\title{
Improvement of the shape memory effect of a Fe-Mn-Cr-Si-Ni by original thermomechanical treatments
}

\author{
L. FEDERZONI ${ }^{*}{ }^{\prime \prime}$, G. GUÉNIN" and M. MANTEL"*
}

* GEMPPM, Bât. 502, Institut National des Sciences Appliquées, 69621 Villeurbanne cedex, France

" Centre de Recherche Ugine, Ugine Savoie, 73403 Ugine cedex, France

\begin{abstract}
Among the shape memory alloys, Fe-based have real perspectives of industrial development. However, to acquire a good shape memory effect, these alloys must undergo a thermomechanical treatment. For applcation perspective this treatment must be the simpliest as possible. In this paper, two types of treatment have been performed, based of the fact that

- the formation of the martensite $\varepsilon$, responsible for the shape memory effect, is sensitive to the microstructure

- its reversibility is the best as possible if the austenite is previously hardened by a deformation at high temperature
\end{abstract}

\section{INTRODUCTION}

Stainless steel Fe-based shape memory alloys have real perspectives of development with respect to their low cost and their good mechanical properties To obtain a good shape memory effect, this alloy has to follow a special thermomechanical treatment called as 'training' [1], [2] and which consists in a succession of deformation at room temperature and heating. With this treatment, it is possible to reach more than $3 \%$ of one-way shape memory effect, which is sensibly the same order of magnitude as for the $\mathrm{Cu}$-based alloys.

Unfortunatly, this thermomechanical treatment is particulary complex and incompatible with an industrial development.

Different ways have been explored to obtain a high shape memory effect without the disadvantages of the cycling related to the 'training' process

\section{EXPERIMENTAL}

An ingot of $\mathrm{Fe}-16 \mathrm{Mn}-9 \mathrm{Cr}-5 \mathrm{Si}-4 \mathrm{Ni}$ was prepared at UGINE-SAVOIE by an usual melting and casting method under argon and hot-rolled into a thick plate and subsequently cold-rolled to $1.2 \mathrm{~mm}$ at room temperature and finally annealed at $850^{\circ} \mathrm{C}$ during $15 \mathrm{~min}$. For this annealing condition, the alloy is perfectly recrystallized ans its $\mathrm{M}_{\mathrm{S}}$ is $\sim 0^{\circ} \mathrm{C}$

Volume fractions of $\varepsilon$-martensite were measured by ThermoElectric Power (TEP) apparatus at room temperature with the technique described in [3]. Samples were cut form the sheet and cleaned by mechanical polishing.

TEP was performed with a difference temperature of $10^{\circ} \mathrm{C}$ (between 15 and $25^{\circ} \mathrm{C}$ ) 
Shape memory measurements were performed in tension on samples of dimensions $10 \times 1.2 \times 80$ $\mathrm{mm}^{3}$. After the deformation, samples were heated at $600^{\circ} \mathrm{C}$ during $15 \mathrm{~min}$ and variations of length between two indentations made by a Vickers hardness tester [fig. 1] were measured with the help of an optical microscope.

With this technique it is possible the measure the shape memory effect (SME) with a relative precision of $\pm 2 \%$

\section{RESULTS AND DISCUSSION}

\section{1. improvement of the SME by a restauration treatment.}

It was reported elsewhere [3] that the volume fraction of thermal $\varepsilon$-martensite can be greatly enhanced by a modification of the microstructure and particulary by a thermomechanical treatment which consists in a deformation followed by an annealing at high temperature.

The figure 2 exhibits results of this treatment on the production of thermal $\varepsilon$-martensite by cooling samples into liquid nitrogen. Deformations are ranged between 0 and $15 \%$ and the annealing temperature is $700^{\circ} \mathrm{C}$ during 45 minutes.

It is seen that the volume fraction of $\varepsilon$-martensite reaches a maximum of $\sim 60 \%$ for a deformation of $\sim 7 \%$ ( and only $5 \%$ martensite for no deformation )

The deformation of $7 \%$ followed by an annealing at $700^{\circ} \mathrm{C}$ has been identified to be related to a critical restauration process which involves an increase of the density of nucleation sites for the $\varepsilon-$ martensite.
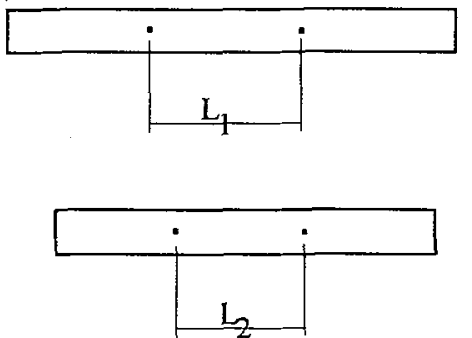

after deformation

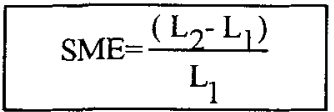

after heating

fig. 1 : shape memory measurement by measurement of distance between indentations

The question is to know if this treatment can improve the SME.

Two different samples A and B respectively recrystallized and optimally treated were prepared and strained at room temperature by different values (from 2 to $14 \%$ ) and the SME was measured as the function of this deformation [fig. 3]. The first observation is that the SME exhibits a maximum for a deformation between 4 and $8 \%$ for both treatments. For lower deformations, the SME is lower but the percentage of recovery ( recovery reported to the deformation ) is higher For higher deformations, the SME decreases. It is classicaly admitted that a too high deformation induces both slip deformation and formation of $\alpha^{\prime}$-martensite which impede the backward movement of partial dislocations responsible for the $\gamma-\varepsilon$ transformation and for the SME.

The most important feature is the improvement of the SME on the sample B if compared with sample $A$, and that for all the deformations lower than $14 \%$. For a deformation of $4 \%$, the SME increases from 1.5 to $2 \%$.

This difference is not important but significative to show that the microstructure of the restaured sample is also favourable to the nucleation of a stress-induced $\varepsilon$-martensite which provides a good shape memory effect. 


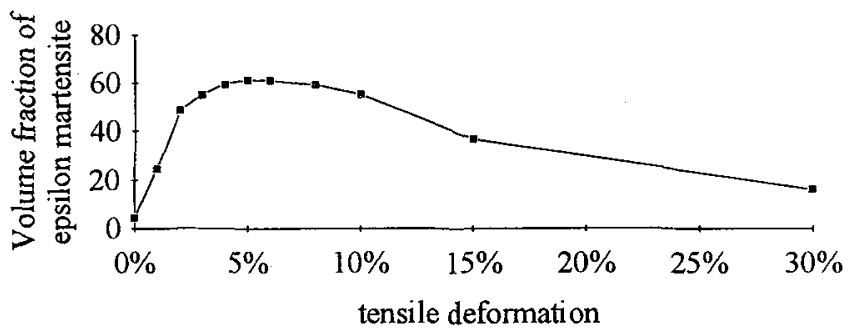

fig 2 : evolution of the volume fraction of $\varepsilon$-martensite with the deformation followed by an annealing at $700^{\circ} \mathrm{C}$ during 45 minutes.

Moreover, we understand how the microstructure of the alloy has an influence on the shape memory effect as was suggested by [4]

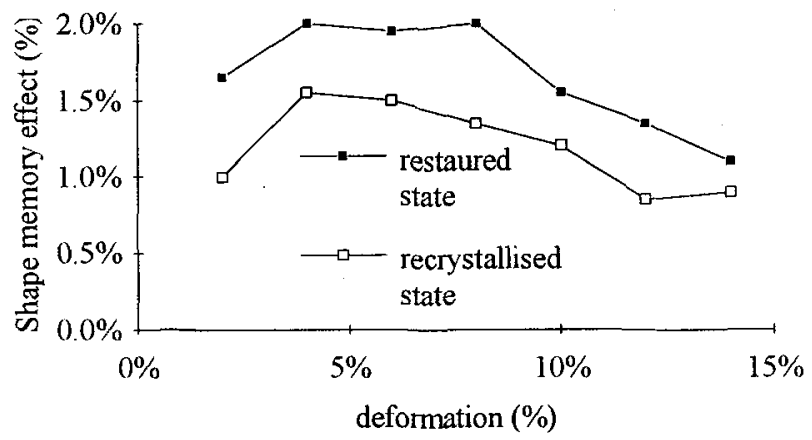

fig. 3 : measurement of the shape memory effect as a function of the deformation.

\section{2. improvement of the shape memory effect by a high temperature deformation}

Based on the fact that the shape memory effect is influenced by the microstructure, a treatment has been imagined to modify this microstructure : samples are strained at different temperatures between 300 and $600^{\circ} \mathrm{C}$ by $5 \%$ tensile deformation. The lower temperature $\left(300^{\circ} \mathrm{C}\right)$ was chosen intentionally higher than $\mathrm{M}_{\mathrm{d}}$ to avoid the formation of stress-induced $\varepsilon$-martensite. In this case, the deformation involves only slip. The higher temperature $\left(600^{\circ} \mathrm{C}\right)$ was also on purpose chosen low enough to avoid a restauration of dislocations.

Then samples are strained by $5 \%$ tensile test and shape memory effect is measured [fig. 4 ]. On the same figure is reported the point corresponding to a deformation of $5 \%$ at room temperature.

It is seen that the deformation at high temperature has the effect to improve significantly the shape memory effect from $1.5 \%$ (without deformation) to $\sim 3 \%$. Moreover, this high shape memory effect seems to be independant on the deformation temperature between 300 and $600^{\circ} \mathrm{C}$. This is not the case between 20 and $300^{\circ} \mathrm{C}$ where the shape memory effect varies from 2.2 to $3 \%$.

For Fe-Ni-C alloys which exhibit a large shape memory effect, it has been established that a deformation of the austenite ( called 'ausforming' ) is really determinant to obtain a good SME [5], because this hardening of the austenite allows the formation of the martensite (without slip deformation) and its reversibility. 
Maki [6] has shown the real importance of the hardness of the austenite on the reversibility of the $\mathcal{E}$-martensite and on the shape memory effect on a Fe-Mn-Si alloy.

This development can be transposed to Fe-Mn-Cr-Si-Ni shape memory alloys and the improvement can be attributed to this hardening.

Another reason of the improvement of the SME is that the introduction of dislocations can be favourable to the formation of stress-induced $\varepsilon$-martensite since dislocations are directly related to the mechanism of the formation of this martensite.

The two explainations contribute to an increase of the SME

\section{CONCLUSION}

It has been found that the SME of a Fe-Mn-Cr-Si-Ni shape memory alloy can be improved without the help of the 'training' process which consists in a repetition of deformations and heating at room temeprature.

Two different ways have been explored :

- the increase of the number of nucleation sites of $\varepsilon$-martensite by a restauration process. This sites can be activated easily by a deformation.

- the hardening of the austenite by a deformation at high temperature ( $>\mathrm{Md})$ which allows a good reversibility of the martensite and a finally a high SME $(\sim 3 \%)$

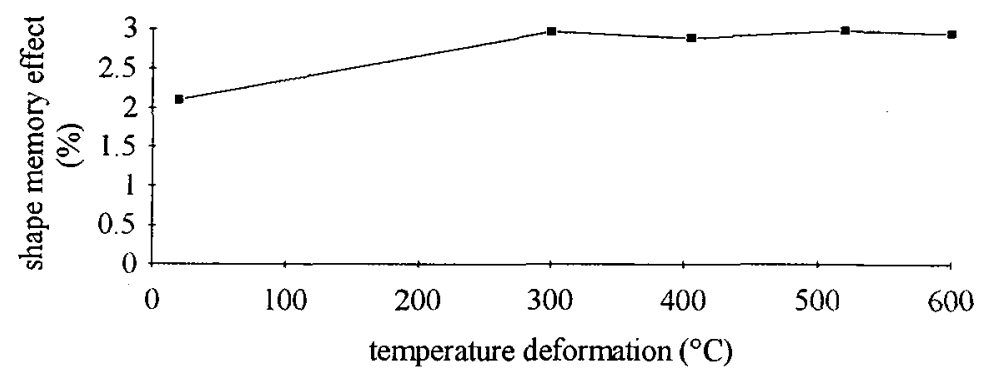

fig 4 : measurement of SME for a deformation of $5 \%$ at room temperature as the function of the temperature of deformation ( $5 \%$ ) of the pre-cycle.

\section{REFERENCES}

[1] Moriya Y., Suzuki H., Hashizume S., Sampei T. and Kozasu I., Proc. International Conference on Stainless Steels, ISIJ, Chiba, (1991), 527.

[2] Inagaki H., Z. Metallkd, 83; (1992), 90.

[3] Federzoni L., Gex D., Gu Q., Guénin G., Labrosse D., Mantel M., Van Humbeeck J.; to appear in the proceedings of ICOMAT-92.

[4] Wang X.X. and Zhao L.C., Scripta metall., 26, (1992), 1451.

[5] Kajiwara S., Trans. of the Japan Inst. of Met., 26(8), (1985), 595.

[6] Maki T, Tsuzaki K., to appear in the proceedings of ICOMAT-92.

\section{ACKNOWLEDGMENTS}

Part of this work is financed by C.E.C.A. $n^{\circ} 7210 / \mathrm{MA} / 314$. 